\title{
PERSEPSI ATLET TERHADAP MACAM, FUNGSI CAIRAN, DAN KADAR HIDRASI TUBUH DI UNIT KEGIATAN MAHASISWA OLAHRAGA UNIVERSITAS NEGERI YOGYAKARTA
}

\author{
Oleh: Cerika Rismayanthi \\ Dosen Pendidikan Kesehatan dan Rekreasi FIK UNY
}

Abstrak

Atlet yang memulai latihan/pertandingan dengan level hidrasi tubuh yang baik akan mempunyai performa daya tahan (endurance), kecepatan respons atau reaksi dan juga performa olahraga yang lebih prima. Hal ini membuat strategi hidrasi yang baik menjadi bagian yang tidak terpisahkan bagi atlet tidak hanya untuk menjaga performa olahraganya namun juga bermanfaat untuk menjaga kesehatan tubuh. Tujuan dari penelitian ini adalah untuk mengetahui persepsi atlet terhadap kebutuhan cairan (hidrasi) baik saat latihan dan recovery pada Unit Kegitan Mahasiswa (UKM) olahraga Universitas Negeri Yogyakarta (UNY).

Penelitian ini merupakan penelitian deskriptif yang bermaksud meneliti dan menemukan informasi sebanyak-banyaknya dari suatu fenomena tertentu. Sampel berjumlah 56 orang. Metode yang dipakai dalam penelitian ini adalah metode survei. Adapun teknik pengumpulan data dalam penelitian ini adalah dengan angket. Populasi dalam penelitian ini adalah atlet yang mengikuti latihan pada Unit Kegiatan Mahasiswa (UKM) UNY. Teknik sampling yang digunakan dalam penelitian ini adalah teknik incidental sampling.

Berdasarkan hasil penelitian ini, didapatkan bahwa persepsi atlet terhadap macam, fungsi dan kebutuhan cairan tubuh pada UKM Olahraga UNY berada pada kategori cukup baik dengan pencapaian skor 59,25 (skala 100). Dari 56 mahasiswa sebagai responden penelitian, 14,3\% mempunyai persepsi terhadap macam, fungsi dan kebutuhan cairan (hidrasi) tubuh yang baik; 53,6 \% persepsinya cukup baik; dan 32,1\% persepsi kurang baik; serta tidak ada responden yang persepsinya berada pada kategori tidak baik. Mayoritas persepsinya berada pada kategori cukup baik $(53,6 \%)$.

Kata Kunci: persepsi atlet, macam fungsi cairan, kadar hidrasi tubuh.

Seorang atlet setiap hari harus memperhatikan kondisi fisiknya agar dapat tampil secara prima dalam setiap pertandingan. Dalam proses latihan dengan tujuan untuk meningkatkan prestasi dalam bidang olahraga, pengaturan makan yang optimal harus mendapat perhatian dari setiap orang yang terlibat. Untuk mengatasinya, atlet harus mengatur keseimbangan antara latihan, social life, dan pemulihan. Dalam latihan apalagi pertandingan faktor pemulihan ini memegang peranan yang sangat penting. Pemulihan lebih cepat apabila berlatih secara kontinu dan akan lebih cepat lagi jika berlatih secara intermitten. Selain kebutuhan nutrisi, atlet juga membutuhkan pengaturan hidrasi yang baik. Beberapa penelitian menunjukkan bahwa salah satu kunci optimalisasi recovery adalah dengan pengaturan hidrasi. Sebagai iliustrasi, kekurangan $2 \%$ kebutuhan hidrasi tubuh ditemukan dapat menghambat performa kerja. Hal ini terjadi mengingat volume darah yang berkurang 


\section{MEDIKORA Vol. IX, No 1 Oktober 2012}

menuntut sistem kardiovaskular dituntut untuk bekerja lebih keras untuk menyesuaikan dengan kebutuhan oksigenasi akibat aktivitas fisik yang pada akhirnya mengurangi performa fisiologis atlet. Selain itu, volume plasma yang rendah juga berdampak pada lambatnya proses eliminasi produk metabolisme hasil aktivitas fisik.

Pemulihan (recovery) adalah mengembalikan kondisi tubuh sebelum pertandingan. Jadi, pengertian itu sangat penting untuk menentukan tindakan-tindakan selanjutnya dari pelatih. Pengertian ini perlu untuk menentukan dalam turnamen serta latihan-latihan dalam pertandingan. Pengisian energi dalam otot tidak sama dengan pengisian bahan bakar pada mesin mobil. Oleh karena itu, sebelum bertanding, latihan itu ditujukan untuk peningkatan cadangan system energy yang bersangkutan sehingga pada waktu turnamen cadangan energy sudah tinggi. Kurangnya konsumsi cairan yang menyebabkan dehidrasi berbahaya bagi kesehatan serta membuat beban kerja tubuh menjadi lebih berat. Pada saat berolahraga, dehidrasi menyebabkan penurunan kemampuan konsentrasi, kecepatan reaksi, meningkatkan suhu tubuh, dan menghambat laju produksi energi. Dehidrasi bersama dengan berkurangnya simpanan karbohidrat merupakan dua faktor utama penyebab penurunan performa tubuh pada saat berolahraga. Oleh karena itu, atlet/penggiat olahraga diharapkan mempunyai strategi minum yang baik agar hidrasi tubuh selalu terjaga. Dengan berbagai alasan seperi 'terasa berat di perut', 'terasa kenyang,' ataupun 'takut sering ke kamar kecil' banyak sekali atlet atapun individu yang tidak memandang penting konsumsi cairan yang cukup sebelum latihan/pertandingan olahraga.

Studi dan hasil riset menunjukkan bawah atlet/individu yang memulai latihan/ pertandingan dengan level hidrasi tubuh yang baik akan mempunyai performa daya tahan (endurance), kecepatan respons, atau reaksi dan juga performa olahraga yang lebih prima. Hal ini membuat strategi hidrasi yang baik menjadi bagian yang tidak terpisahkan bagi atlet profesional dunia, tidak hanya untuk menjaga performa olahraga namun juga bermanfaat untuk menjaga kesehatan tubuh. Cara yang paling mudah dan akurat untuk mengetahui status/level hidrasi tubuh sebelum olahraga adalah dengan melihat warna dan volume urin pada saat buang air kecil. Warna urin cerah dengan volume yang banyak menunjukan level hidrasi yang baik, sedangkan warna urin yang gelap atau keruh dengan volume yang sedikit menunjukan level hidrasi yang rendah di dalam tubuh.

Secara ideal pada saat latihan atau juga dalam pertandingan atlet disarankan untuk minum air secara rutin agar level hidrasi di dalam tubuh dapat terjaga. Penting bagi atlet untuk dapat menjaga level hidrasi di dalam tubuh melalui pola konsumsi cairan secara rutin baik pada saat sebelum dan sedang berolahraga dan setelah berolahraga agar fungsi- 


\section{MEDIKORA Vol. IX, No 1 Oktober 2012}

fungsi tubuh dapat berjalan dengan baik terutama fungsi termoregulasi (pangaturan panas). Dengan pola konsumsi rutin ini juga diharapkan agar berkurangnya cairan dari dalam tubuh pada saat latihan/pertandingan tidak melebihi $2 \%$, karena pada nilai lebih dari $2 \%$ performa tubuh sudah berkurang sebesar $10 \%$.

\section{KAJIAN PUSTAKA}

\section{Hidrasi}

Hidrasi diartikan sebagai keseimbangan cairan dalam tubuh dan merupakan syarat penting untuk menjamin fungsi metabolisme sel tubuh. Sementara itu, dehidrasi berarti kurangnya cairan di dalam tubuh karena jumlah yang keluar lebih besar dari jumlah yang masuk. Jika tubuh kehilangan banyak cairan, tubuh akan mengalami dehidrasi. Ada tiga jenis dehidrasi, yaitu: (1) hypotonic adalah tubuh kehilangan larutan elektrolit (garam, kalium, klor, kalsium, dan pospat, (2) hypertronic adalah tubuh kehilangan air, dan (3) isotonic adalah tubuh kehilangan air dan larutan elektrolit, kondisi ini paling sering terjadi. Bahaya dehidrasi adalah kemampuan kognitif menurun karena sulit berkonsentrasi, risiko infeksi saluran kemih, dan terbentuknya batu ginjal, minum yang cukup dan jangan menahan air kemih adalah cara yang paling efektif untuk mencegah infeksi saluran kemih, serta menurunkan stamina dan produktivitas kerja melalui gangguan sakit kepala, lesu, kejang hingga pingsan. Kehilangan cairan lebih dari $15 \%$ akan berakibat fatal.

Menurut Murray (2007: 238), penanganan dehidrasi umumnya yang terjadi adalah dehidrasi ringan sampai menengah, sehingga dapat diatasi dengan minum untuk mengganti cairan tubuh yang keluar. Kebutuhan air minum memang beragam. Hal ini bergantung pada usia, jenis kelamin, dan aktivitas. Jumlah kebutuhan tubuh akan air adalah 1 mililiter per kilo kalori kebutuhan energi tubuh. Misalnya, pada remaja dan dewasa yang kebutuhan energinya 1800-3000 kkal, kebutuhan cairan berkisar 1.8-3 liter sehari. Umumnya 1/3-nya dipenuhi dari makanan, maka konsumsi air yang diminum langsung sekitar 2 liter sehari. Jus buah merupakan salah satu cara untuk memenuhi kebutuhan cairan tubuh. Selain dapat memenuhi kebutuhan tubuh akan cairan, jus buah juga banyak mengandung antioksidan yang sangat penting untuk kesehatan.

Kadar hidrasi dapat ditandai lewat warna urin yang dikeluarkan. Inilah panduannya untuk menandai seseorang terserang dehidrasi akut atau tidak. Untuk memastikan bahwa tubuh manusia tidak kekurangan cairan, setiap orang dapat melihatnya dari pengecekan warna urin yang dikeluarkan. Tingkatan warna urin menunjukkan keadaan dan keseimbangan air dalam tubuh. Apabila urin berwarna jernih, ini menunjukkan status hidrasi tubuh yang 


\section{MEDIKORA Vol. IX, No 1 Oktober 2012}

baik. Apabila urin menunjukkan warna orange pekat, ini menunjukkan perlu tubuh mendapat lebih banyak asupan air segera agar kehilangan cairan tubuh dapat segera diganti dan kondisi cairan tubuh tetap seimbang. Dalam berolahraga, konsumsi cairan yang cukup serta melengkapinya dengan mengkonsumsi nutrisi yang baik akan membantu tubuh untuk dapat berlatih lebih lama, mencegah kelelahan dini, secara efisien membantu meningkatkan skill serta akan membantu mempercepat proses recovery setelah latihan/pertandingan. Di bawah ini adalah kadar warna urin yang menggambarkan keadaan hidrasi seseorang.

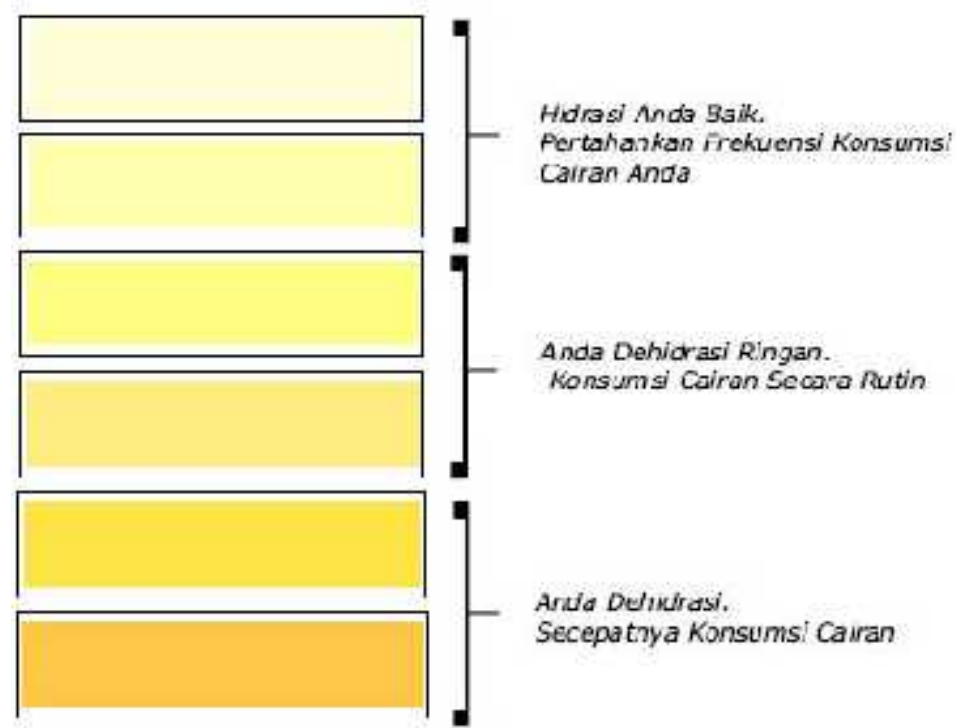

Gambar 1. Indikator Kadar Hidrasi Seseorang

(Sumber: Journal of Sports Science and Medicine, JSSM: 2002)

Beberapa cara dapat digunakan untuk membantu menjaga ketersediaan cairan di dalam tubuh, antara lain: (1) konsumsi cairan secara rutin dianjurkan untuk tidak mengunakan rasa haus sebagai indikator untuk minun, (2) timbang berat badan pada saat sebelum dan sesudah latihan; setiap berkurangnya $1 \mathrm{~kg}$ berat badan sama dengan kehilangan 1 liter cairan dari dalam tubuh; konsumsi sekurangnya 1 liter air tiap berkurang $1 \mathrm{~kg}$ berat badan; (3) gunakan warna urin sebagai indikator. Warna urin yang semakin keruh/gelap serta volumenya yang sedikit menandakan kurangnya cairan di dalam tubuh. Warna urin yang cerah/pucat dan volumenya banyak menandakan tingkat hidrasi yang baik di dalam tubuh. Beberapa jenis obat, supplement atau juga vitamin dapat memengaruhi warna urin sehingga dapat menyebabkan warna urin pada hydration chart menjadi tidak akurat.

\section{KEBUTUHAN CAIRAN DALAM TUBUH SAAT LATIHAN DAN RECOVERY}

Latihan adalah suatu proses berlatih secara sistematis yang dilakukan secara berulangulang dengan beban latihan yang kian bertambah (Timothy, 2004: 17). Hal senada juga 


\section{MEDIKORA Vol. IX, No 1 Oktober 2012}

dikemukakan oleh Mosston (1992: 9) bahwa latihan merupakan pelaksanaan gerakan secara berurutan dan berulang-ulang. Pada prinsipnya latihan memberikan tekanan fisik secara teratur, sistematik, berkesinambungan sedemikian rupa sehingga dapat meningkatkan kemampuan fisik di dalam melakukan aktivitas (Fox, 1993: 69). Latihan fisik merupakan pemberian atau beban fisik pada tubuh secara teratur, sistematis, dan berkesinambungan melalui program latihan yang tepat (Timothy, 2004: 21).

Menurut Powers (2007: 53) latihan fisik adalah aktivitas fisik yang dilakukan secara terencana dengan tujuan untuk meningkatkan atau memelihara kebugaran jasmani. Latihan fisik sebaiknya dilakukan sesuai dengan kemampuan tubuh dalam menanggapi stres yang diberikan, apabila tubuh diberi beban latihan yang terlalu ringan, tidak akan terjadi proses adaptasi (Sugiharto, 2003: 4). Demikian juga jika diberikan beban latihan yang terlalu berat dan tubuh tidak mampu memberikan toleransi, akan menyebabkan terganggunya proses homeostasis pada sistem tubuh dan dapat mengakibatkan kerusakan. Setiap latihan fisik atau latihan akan menimbulkan respons atau tanggapan dari organ-organ tubuh terhadap dosis atau beban latihan yang diberikan, hal ini merupakan usaha penyesuaian diri dalam rangka menjaga keseimbangan lingkungan.

Aktivitas fisik dengan intensitas tinggi yang dilaksanakan secara terus menerus dapat menimbulkan kelelahan dan stres fisik. Fase recovery diperlukan untuk membantu tubuh beradaptasi terhadap stres, meningkatakan kualitas fisik dan psikis, sekaligus mengurangi risiko cedera. Masa recovery bagi atlet sangat vital untuk dilakukan pada masa latihan maupun masa kompetisi. Pada atlet elit, peran penting manajemen recovery bahkan sangat berpengaruh pada hasil prestasi yang dicapai. Hal tersebut antara lain diungkapkan oleh

Barry Barney yang merupakan pelatih tim Basket Australia dalam Olimpiade Atlanta 1996 dalam Calder (2003: 136) sebagai berikut: "If there was one single factor that helped this team to perform to the level they did at Atlanta Olympic, it was the recovery program that was put in place and monitored throughout our 1996 program." Pentingnya faktor recovery tersebut sangat erat kaitanntya dengan adaptasi fisiologis terhadap kelelahan (stres fisik dan psikologis).

Faktor penyebab kelelahan sangat kompleks, baik itu berasal dari kondisi fisiologis maupun kondisi psikologis atlet. Lebih lanjut, Horner et.al (2007) mengemukakan bahwa berdasarkan sumber terjadinya, kelelahan dikategorikan dalam lima kelompok besar: (1) kelelahan metabolik, terkait dengan menipisnya cadangan energi yang berasal dari ATP, kreatin fosfat, glikogen atau glukosa, dan akumulasi laktat di otot, gangguan homeostasis, misalnya gangguan osmolaritas plasma, volume plasma, penurunan $\mathrm{pH}$ cairan tubuh, dan 


\section{MEDIKORA Vol. IX, No 1 Oktober 2012}

penurunan kadar elektrolit cairan tubuh, (2) kelelahan neurologis (kelelahan pada otot akibat berkurangnya kapasitas kerja sistem neuromuskular), (3) kelelahan neurologis atau berkurangnya kapasitas kerja sistem saraf pusat, (4) kelelahan psikologis (terkait kondisi sosial, emosional, dan kultural), (5) kelelahan akibat perjalanan dan kondisi lingkungan, baik itu suhu maupun kelembaban udara. Pada prinsipnya, recovery merupakan usaha untuk mempercepat tubuh untuk mengompensasi kelelahan (stress fisik maupun psikis). Stress fisik dan psikis akan menurunkan performa fisiologis atlet. Pada umumnya, tanpa proses recovery yang optimal, tubuh akan terus mengalami penurunan fungsi. Teknik recovery yang optimal dapat memperbaiki kembali penurunan fungsi tubuh bahkan dapat mengarah pada keadaan supercompesation yang pada batas tertentu terjadi peningkatan kapasitas fisiologis diatas semula (Kovacs, 2006: 84).

Air di dalam tubuh membentuk sekitar 50-60 \% dari total berat badan. Hal ini adalah 35-42 liter untuk individu dengan berat badan $70 \mathrm{~kg}$ merupakan jumlah berat air. Air di dalam tubuh mempunyai fungsi penting diantaranya, yaitu: (1) mengangkut nutrisi \& oksigen ke dalam sel-sel tubuh, (2) mengatur suhu tubuh, (3) membantu proses pencernaan, (4) pelumas dalam pergerakan sendi, dan (5) tempat produksi energi. Kurangnya konsumsi cairan yang menyebabkan dehidrasi berbahaya bagi kesehatan serta membuat beban kerja tubuh menjadi lebih berat. Pada saat berolahraga dehidrasi menyebabkan penurunan kemampuan konsentrasi, kecepatan reaksi, meningkatkan suhu tubuh dan menghambat laju produksi energi. Dehidrasi bersama dengan berkurangnya simpanan karbohidrat merupakan dua faktor utama penyebab penurunan performa tubuh saat olahraga. Oleh karena itu, atlet/penggiat olahraga diharapkan mempunyai strategi minum yang baik agar hidrasi tubuh selalu terjaga.

\section{METODE PENELITIAN}

\section{Desain Penelitian}

Penelitian ini merupakan penelitian deskriptif yang bermaksud meneliti dan menemukan informasi sebanyak-banyaknya dari suatu fenomena tertentu. Jika dikaitkan dengan substansinya, peneliti ingin mengetahui bagaimana persepsi atlet terhadap macam, fungsi dan kebutuhan cairan tubuh pada UKM Olahraga UNY.

\section{Sampel Penelitian}

Populasi adalah keseluruhan subjek penelitian (Suharsimi Arikunto, 2006: 30). Populasi dalam penelitian ini adalah atlet yang mengikuti latihan pada UKM Olahraga UNY. 


\section{MEDIKORA Vol. IX, No 1 Oktober 2012}

Teknik sampling yang digunakan dalam penelitian ini adalah teknik incidental sampling yang dilakukan dengan cara memperoleh sampel dari sekumpulan populasi, yang cara untuk memperoleh data tersebut dengan cara insidental atau kebetulan saja tidak menggunakan perencanaan tertentu (Mardalis, 1995: 59). Sampel tersebut berjumlah 56 orang.

\section{Instrumen Penelitian}

Metode yang dipakai dalam penelitian ini adalah metode survei. Adapun instrumen untuk mengumpulkan data menggunakan angket yang berupa sejumlah pertanyaaan. Instrumen yang berupa angket ini untuk memfokuskan pada masalah persepsi atlet terhadap macam, fungsi, dan kebutuhan hidrasi tubuh. Teknik pengumpulan data dalam penelitian ini adalah dengan angket. Teknik angket ini dugunakan untuk mengetahui persepsi atlet terhadap macam, fungsi dan kebutuhan hidrasi tubuh pada UKM Olahraga UNY. Peneliti menggunakan angket tertutup, yaitu seorang responden tinggal memilih jawaban yang telah disediakan dan mengisi jawaban sesuai dengan pengalaman dan pengetahuannya sendiri.

\section{Hasil Penelitian dan Pembahasan}

\section{Deskripsi Analisis Data}

Pengambilan data pada penelitian digunakan instrumen berupa angket tentang persepsi atlet terhadap macam, fungsi, dan kebutuhan cairan (hidrasi) tubuh, dengan pertanyaan/ pernyataan berjumlah 50 item. Skala pengukuran pada penelitian ini digunakan skala dikotomis (1 dan 0) atau skala Guttman, sehingga diperoleh rentangan skor antara 0 sampai dengan 50. Untuk memudahkan dalam menganalisis data, skor diubah menjadi skala rasio atau persentase pencapaian, dengan cara jumlah jawaban 1 dibagi dengan jumlah item dan dikalikan 100; sehingga diperoleh rentangan skor antara 0 sampai dengan 100. Hal ini ditempuh, karena analisis deskripsi pada penelitian ini meliputi analisis secara keseluruhan dan analisis pada tiap-tiap faktor. Berdasarkan skala persentase pencapaian tersebut, diperoleh rentangan skor antara 0 sampai dengan 100; sehingga diperoleh mean ideal $=50,00$ dan SD ideal 16,67. Dari mean dan SD ideal tersebut dapat ditentukan kriteria penilaian evaluasi pada penelitian ini, dan disajikan pada Tabel 1 berikut ini.

Tabel 1. Kriteria Penafsiran Persepsi Responden terhadap Macam, Fungsi, dan Kebutuhan Hidrasi Tubuh pada UKM Olahraga UNY

\begin{tabular}{|c|c|c|c|}
\hline No. & $\begin{array}{c}\text { Norma } \\
\text { Penilaian }\end{array}$ & Rentang Skor & Interpretasi \\
\hline 1. & $\mathrm{M}+1,5 \mathrm{SD}$ s/d M+3SD & $75,01-100,00$ & Baik \\
\hline 2. & $\mathrm{M} \mathrm{s} / \mathrm{d} \mathrm{M}+1,5 \mathrm{SD}$ & $50,01-75,00$ & Cukup Baik \\
\hline 3. & Mi-1,5SDi s/d Mi & $25,01-50,00$ & Kurang Baik \\
\hline 4. & Mi-3SD s/d Mi-1,5SDi & $0,00-25,00$ & Tidak Baik \\
\hline
\end{tabular}


Berdasarkan analisis data dengan bantuan software komputer, diperoleh rerata (mean) skor persepsi atlet terhadap macam, fungsi, dan kebutuhan cairan tubuh pada UKM Olahraga UNY. sebesar 59,25; median 59,00; modus 44,00 dan standar deviasi sebesar 16,03. Rerata skor tersebut berada pada interval kelas 50,01 s.d. 75,00 kategori cukup baik. Persepsi atlet terhadap macam, fungsi, dan kebutuhan cairan tubuh pada UKM Olahraga UNY. Berdasarkan Pengategoriannya dapat dilihat pada Tabel 2 berikut ini.

Tabel 2. Distribusi Persepsi terhadap Kebutuhan Cairan pada UKM Olahraga UNY

\begin{tabular}{|c|c|c|c|}
\hline \multirow{2}{*}{ No. } & \multirow{2}{*}{ Kategori Skor } & \multicolumn{2}{|c|}{ Frekuensi } \\
\cline { 3 - 4 } & & n & \% \\
\hline 1. & Baik & 8 & 14,3 \\
\hline 2. & Cukup Baik & 30 & 63,6 \\
\hline 3. & Kurang Baik & 18 & 32,1 \\
\hline 4. & Tidak Baik & 0 & 0,0 \\
\hline \multicolumn{2}{|c}{} \\
\hline
\end{tabular}

Dari tabel dan histogram tersebut di atas, diketahui bahwa dari 56 mahasiswa sebagai responden penelitian, 14,3\% mempunyai persepsi terhadap kebutuhan cairan (hidrasi) yang baik; 53,6 \% persepsinya cukup baik; dan 32,1\% persepsinya kurang baik; serta tidak ada responden yang persepsinya berada pada kategori tidak baik. Analisis berikutnya adalah menganalisis pada tiap-tiap faktor dari persepsi terhadap kebutuhan cairan tubuh pada UKM Olahraga UNY. Hasil perhitungan rerata tiap-tiap faktor dari persepsi terhadap kebutuhan cairan tubuh pada UKM Olahraga UNY dapat dilihat pada tabel 3 di bawah ini.

Tabel 3. Hasil Perhitungan Rerata pada Tiap-Tiap Faktor Persepsi terhadap Macam, Fungsi, dan Kebutuhan Cairan Tubuh pada UKM Olahraga UNY

\begin{tabular}{|l|l|c|c|c|l|}
\hline No. & \multicolumn{1}{|c|}{ Faktor } & $\begin{array}{c}\text { Jumlah } \\
\text { Item }\end{array}$ & n & Rerata & \multicolumn{1}{|c|}{ Kategori } \\
\hline 1. & Fungsi Cairan & 9 & 56 & 75,60 & Baik \\
\hline 2. & Kadar Hidrasi Tubuh & 12 & 56 & 56,40 & Cukup Baik \\
\hline 3. & Macam Cairan & 7 & 56 & 44,13 & Kurang Baik \\
\hline \multicolumn{2}{|c|}{$\begin{array}{c}\text { Total (Persepsi terhadap } \\
\text { Kebutuhan Cairan) }\end{array}$} & 50 & 56 & 59,25 & Cukup Baik \\
\hline
\end{tabular}

\section{Faktor 1: Fungsi Cairan}




\section{MEDIKORA Vol. IX, No 1 Oktober 2012}

Berdasarkan analisis data dengan bantuan software komputer diketahui persepsi terhadap fungsi cairan pada mahasiswa di UKM Olahraga UNY, diperoleh rerata (mean) sebesar 75,60; median 77,78; modus 77,78 dan standar deviasi sebesar 20,72. Rerata skor tersebut berada pada interval kelas 75,01 s.d. 100,00 kategori baik. Dengan demikian dapat dikatakan bahwa persepsi mahasiswa UKM Olahraga UNY terhadap faktor fungsi cairan pada variabel kebutuhan cairan berada pada kategori baik. Persepsi mahasiswa UKM Olahraga UNY terhadap faktor fungsi cairan pada variabel, kebutuhan cairan berdasarkan pengkategoriannya dapat dilihat pada Tabel 4 berikut ini.

Tabel 4. Distribusi Persepsi terhadap Fungsi Cairan pada Kebutuhan Cairan pada Mahasiswa UKM Olahraga UNY

\begin{tabular}{|c|c|c|c|}
\hline \multirow{2}{*}{ No. } & \multirow{2}{*}{ Kategori Skor } & \multicolumn{2}{|c|}{ Frekuensi } \\
\cline { 3 - 4 } & Baik & 32 & n \\
\hline 1. & Cukup Baik & 21 & 37,5 \\
\hline 2. & Kurang Baik & 3 & 5,4 \\
\hline 3. & Tidak Baik & 0 & 0,0 \\
\hline 4. & Total & $\mathbf{5 6}$ & $\mathbf{1 0 0 , 0}$ \\
\hline \multicolumn{2}{|c}{} \\
\hline
\end{tabular}

Berdasarkan tabel di atas, diketahui bahwa dari 56 orang mahasiswa UKM Olahraga UNY; 57,1 \% mempunyai persepsi terhadap fungsi cairan berada pada kategori baik; 37,5 \% cukup baik; dan 5,4 \% persepsinya kurang baik; serta tidak ada mahasiswa yang persepsinya berada pada kategori tidak baik. Mayoritas responden persepsinya berada pada kategori baik $57,1 \%$.

\section{Faktor 2: Macam Cairan}

Hasil analisis terhadap data persepsi terhadap macam cairan pada mahasiswa di UKM UNY, diperoleh rerata (mean) sebesar 44,13; median 42,86; modus 14,29 dan standart deviasi sebesar 28,35. Rerata skor tersebut berada pada interval kelas 25,01 s.d. 50,00 kategori kurang baik. Dengan demikian dapat dikatakan bahwa persepsi mahasiswa UKM Olahraga UNY terhadap faktor macam cairan pada variabel kebutuhan cairan (hidrasi) tubuh berada pada kategori kurang baik. Persepsi mahasiswa UKM Olahraga UNY terhadap faktor macam cairan pada variabel kebutuhan cairan tubuh berdasarkan pengkategoriannya dapat dilihat pada Tabel 5 berikut ini.

Tabel 5. Distribusi Persepsi Terhadap Macam, Fungsi Dan Kebutuhan Cairan Tubuh pada Mahasiswa UKM Olahraga UNY 


\begin{tabular}{|c|c|c|c|}
\hline \multirow{2}{*}{ No. } & \multirow{2}{*}{ Kategori Skor } & \multicolumn{2}{|c|}{ Frekuensi } \\
\cline { 3 - 4 } & Baik & 8 & n \\
\hline 1. & Cukup Baik & 13 & 14,3 \\
\hline 2. & Kurang Baik & 19 & 23,2 \\
\hline 3. & Tidak Baik & 16 & 33,9 \\
\hline 4. & Total & 56 & 100,6 \\
\hline \multicolumn{2}{|c}{} \\
\hline
\end{tabular}

Berdasarkan tabel di atas, diketahui bahwa dari 56 orang mahasiswa UKM UNY; 14,3 $\%$ mempunyai persepsi terhadap macam cairan berada pada kategori baik; 23,2 \% cukup baik; 33,9 \% persepsinya kurang baik; dan 28,6 \% persepsinya berada pada kategori tidak baik. Mayoritas responden persepsinya berada pada kategori kurang baik 33,9\%.

\section{Faktor 3: Kadar Hidrasi Tubuh}

Hasil analisis terhadap data persepsi terhadap kadar hidrasi tubuh pada mahasiswa di UKM UNY, diperoleh rerata (mean) sebesar 56,40; median 58,33; modus 50,00 dan standart deviasi sebesar 20,72. Rerata skor tersebut berada pada interval kelas 50,01 s.d. 75,00 kategori cukup baik. Dengan demikian dapat dikatakan bahwa persepsi mahasiswa UKM UNY terhadap faktor kadar hidrasi tubuh pada variabel kebutuhan cairan tubuh berada pada kategori cukup baik. Persepsi mahasiswa UKM UNY terhadap faktor kadar hidrasi tubuh pada variabel kebutuhan cairan tubuh berdasarkan pengkategoriannya dapat dilihat pada Tabel 6 berikut ini.

Tabel 6. Distribusi Persepsi Terhadap Macam, Fungsi Dan Kebutuhan Cairan Tubuh pada Mahasiswa UKM Olahraga UNY

\begin{tabular}{|c|c|c|c|}
\hline \multirow{2}{*}{ No. } & \multirow{2}{*}{ Kategori Skor } & \multicolumn{2}{|c|}{ Frekuensi } \\
\cline { 3 - 4 } & & $\mathbf{n}$ & $\mathbf{\%}$ \\
\hline 1. & Baik & 7 & 12,5 \\
\hline 2. & Cukup Baik & 23 & 41,1 \\
\hline 3. & Kurang Baik & 19 & 33,9 \\
\hline 4. & Tidak Baik & 7 & 12,5 \\
\hline \multicolumn{2}{|c|}{ Total } & 56 & 100,0 \\
\hline
\end{tabular}

Berdasarkan tabel di atas, diketahui bahwa dari 56 orang mahasiswa UKM UNY; 12,5 $\%$ mempunyai persepsi terhadap kadar hidrasi tubuh berada pada kategori baik; 41,1 \% cukup baik; 33,9 \% persepsinya kurang baik; dan 12,5\% persepsinya berada pada kategori tidak baik. Mayoritas responden persepsinya berada pada kategori cukup baik 41,1\%.

\section{Pembahasan}




\section{MEDIKORA Vol. IX, No 1 Oktober 2012}

Penelitian ini membuktikan bahwa persepsi atlet terhadap macam, fungsi, dan kebutuhan cairan tubuh pada UKM Olahraga UNY berada pada kategori cukup baik dengan pencapaian skor 59,25 (skala 100). Dari 56 mahasiswa sebagai responden penelitian, 14,3\% mempunyai persepsi terhadap macam, fungsi, dan kebutuhan cairan tubuh yang baik; 53,6\% persepsinya cukup baik; dan 32,1 \% persepsinya kurang baik; serta tidak ada responden yang persepsinya berada pada kategori tidak baik. Mayoritas persepsinya berada pada kategori cukup baik 53,6\%.

\section{Persepsi terhadap Fungsi Cairan}

Hasil analisis data membuktikan bahwa persepsi mahasiswa terhadap fungsi cairan pada persepsi atlet terhadap macam, fungsi, dan kebutuhan cairan tubuh di UKM Olahraga UNY, berada pada kategori baik dengan pencapaian skor 75,60 (skala 100). Dari 56 orang mahasiswa UKM UNY; 57,1 \% mempunyai persepsi terhadap fungsi cairan berada pada kategori baik; 37,5 \% cukup baik; dan 5,4 \% persepsinya kurang baik; serta tidak ada mahasiswa yang persepsinya berada pada kategori tidak baik. Mayoritas responden persepsinya berada pada kategori baik (57,1\%). Fungsi cairan tubuh antara lain: (a) mengatur suhu tubuh, apabila kekurangan air, suhu tubuh akan menjadi panas dan naik, (b) melancarkan peredaran darah, jika tubuh seseorang kurang cairan, darah akan mengental; hal ini disebabkan cairan dalam darah tersedot untuk kebutuhan dalam tubuh; proses tersebut akan berpengaruh pada kinerja otak dan jantung; (c) membuang racun dan sisa makanan, tersedianya cairan tubuh yang cukup dapat membantu mengeluarkan racun dalam tubuh; air membersihkan racun dalam tubuh melalui keringat, air seni, dan pernapasan, (d) air sangat penting untuk mengatur struktur dan fungsi kulit; kecukupan air dalam tubuh berguna untuk menjaga kelembaban, kelembutan, dan elastisitas kulit akibat pengaruh suhu udara dari luar tubuh, (e) peran air dalam proses pencernaan untuk mengangkut nutrisi dan oksigen melalui darah untuk segera dikirim ke sel-sel tubuh. (f) cairan tubuh melindungi dan melumasi gerakan pada sendi dan otot. Otot tubuh akan mengempis apabila tubuh kekurangan cairan; oleh sebab itu, perlu minum air dengan cukup selama beraktivitas untuk meminimalisasi risiko kejang otot dan kelelahan.

\section{Persepsi terhadap Macam Cairan}

Nilai dan fungsi air dimulai dari anggapan salah, antara lain bahwa air semata-mata cairan sederhana yang melarutkan dan menyirkulasi berbagai hal dalam tubuh. Kenyataannya, air memiliki kepentingan mempertahankan hidup (life-sustaining properties) sekaligus sebagai pemberi fungsi kehidupan. Ada kondisi pada saat tubuh manusia tidak mampu mengatur pemasukan air secara efisien. Usia senja, misalnya. 


\section{MEDIKORA Vol. IX, No 1 Oktober 2012}

Persepsi rasa haus dan gangguan menelan menyebabkan tubuh kekurangan air secara kronik dan menyebabkan kematian di ambang pintu. Tidak ada satu cairanpun yang mampu menyamai air murni.

Air murnilah yang dibutuhkan tubuh, karena sifatnya yang mampu melewati batasan-batasan seluler. Air murni pun dapat membawa pengaruh bagi tubuh manusia, seperti gula, kafein, pewarna, dan pemanis. Hasil analisis data membuktikan bahwa persepsi mahasiswa terhadap macam cairan pada persepsi atlet terhadap macam, fungsi, dan kebutuhan cairan tubuh di UKM Olahraga UNY; berada pada kategori kurang baik dengan pencapaian skor 44,13 (skala 100). Dari 56 orang mahasiswa UKM UNY; 14,3\% mempunyai persepsi terhadap macam cairan berada pada kategori baik; 23,2 \% cukup baik; 33,9 \% persepsinya kurang baik; dan 28,6 \% persepsinya berada pada kategori tidak baik. Mayoritas responden persepsinya berada pada kategori kurang baik 33,9\%.

\section{Persepsi terhadap Kadar Hidrasi Tubuh}

Hidrasi diartikan sebagai keseimbangan cairan dalam tubuh dan merupakan syarat penting untuk menjamin fungsi metabolisme sel tubuh. Sementara itu, dehidrasi berarti kurangnya cairan di dalam tubuh karena jumlah yang keluar lebih besar dari pada jumlah yang masuk. Kebutuhan air minum memang beragam. Hal ini bergantung pada usia, jenis kelamin, dan aktivitas. Jumlah kebutuhan tubuh akan air adalah 1 mililiter per kilo kalori kebutuhan energi tubuh. Hasil analisis data membuktikan bahwa persepsi mahasiswa terhadap macam, fungsi, dan kebutuhan cairan tubuh di UKM Olahraga UNY; berada pada kategori cukup baik dengan pencapaian skor 56,40 (skala 100). Dari 56 orang mahasiswa UKM UNY; 12,5 \% mempunyai persepsi terhadap kadar hidrasi tubuh berada pada kategori baik; 41,1 \% cukup baik; 33,9 \% persepsinya kurang baik; dan 12,5\% persepsinya berada pada kategori tidak baik. Mayoritas responden persepsinya berada pada kategori cukup baik $41,1 \%$.

\section{KESIMPULAN}

Pada saat berolahraga, konsumsi cairan yang cukup serta melengkapinya dengan mengonsumsi nutrisi yang baik akan membantu tubuh untuk dapat berlatih lebih lama, mencegah kelelahan dini, secara efisien membantu meningkatkan skill serta akan membantu mempercepat proses recovery setelah latihan/pertandingan. Setelah latihan/pertandingan olahraga ada dua faktor yang harus cepat dipasok kembali ke dalam tubuh yaitu cairan untuk mengantikan keringat yang keluar serta nutrisi karbohidrat untuk mengisi kembali simpanan 'bahan bakar' yang terpakai saat olahraga. 


\section{MEDIKORA Vol. IX, No 1 Oktober 2012}

Beberapa anjuran untuk menjaga level hidrasi seorang atlet adalah sebagai berikut: (1) minum sekurangnya 1-1,5 liter cairan untuk tiap berkurangnya $1 \mathrm{~kg}$ berat badan. (2) minum secara bertahap dalam interval 0-2 jam setelah olahraga; pilihan minuman: air putih, minuman olahraga atau jus buah segar (encer), (3) minuman olahraga dan jus buah segar (encer) dapat secara simultan memasok karbohidrat dan cairan dengan cepat untuk tubuh, (4) alternatif lain untuk memasok karbohidrat dan cairan untuk tubuh adalah kombinasi buah segar dan air putih. Pilih buah segar yang dapat diserap tubuh dengan cepat sehingga lebih optimal dalam mengantikan energi setelah olahraga: pepaya, semangka, pisang, kismis, dan (5) perhatikan kembali warna urin untuk memastikan level hidrasi yang baik.

\section{DAFTAR PUSTAKA}

Calder, A. (2003). Recovery Strategies For Sports Performance. USOC Olympic Coach EMagazine [online]. Retrieved February 6: 2006.

Dougherty, K. A., L. B. Baker, M. Chow and W. L. Kenney (2006). Two Percent Dehydration Impairs And Six Percent Carbohydrate Drink Improves Boys Basketball Skills. Medicine \& Science in Sports \& Exercise 38(9): 1650.

FIFA/F-Marc International Consensus Conference on Nutrition for Football. (2005).

Hornery, D. J., D. Farrow, I. Mujika and W. Young (2007). Fatigue In Tennis: Mechanisms Of Fatigue And Effect On Performance. Sports Medicine 37(3): 199-212.

Kovacs, M. S. (2006). Applied Physiology Of Tennis Performance. British Journal of Sports Medicine 40 (5): 381.

Louise M. Burke is with the. (2006) Journal of Sports Sciences, Vol 24, No. 7, 699707(9).2006 Dept. of Sports Nutrition, Australian Institute of Sport, Canberra, Australia.

Murray, B. (2007). Hydration and physical performance. Journal of the American College of Nutrition 26 (Supplement 5): 542S.

Moston, Muska. (1992). Teaching Physical Education. Ohio: Charles E. Meribt Publishing Company.

Powers. (2002). Medicine and Science in Sports and Exercise. Rev Bras Med Esporte, Vol.9 no.4. 2003. University of Cape Town.

Soccer and Science. (2000). Institute of Exercise and Sport Sciences, University of Copenhagen. 
MEDIKORA Vol. IX, No 1 Oktober 2012

Sports Nutrition. (2004). An Introduction to Energy Production and Performance. Human Kinetics.

Timothy. (2004). Journal of Sports Science Institute, 3, 198-202. 2004. Sports Science Institute of S. Africa, Newlands. 